\title{
Regulation of PTPID mRNA by Peptide Growth Factors in the Human Endometrial Cell Line HEC-I-A
}

\author{
James J. Burke II, MD, Francisco Talavera, $\mathrm{PhD}$, and K. M. J. Menon, $\mathrm{PhD}$
}

\begin{abstract}
OBJECTIVE: To assess, in the human endometrial cell line HEC-1-A, the presence of protein tyrosine phosphatase $1 D$ (PTP1D) and the possible regulation of its $m R N A$ expression by mitogens such as forskolin (an agent that increases intracellular cyclic adenosine monophosphate (cAMP] levels), cpidcrmal growth factor (EGF), and insulin-like growth factor-I (IGF-I).

METHODS: Cells were groun to confluence and maintained in serum-free media for 24 hours before treatment. Cells were exposed to forskolin, EGF, and IGF-I for increasing time periods $(0,1,3$, 6, and 24 hours), and PTP1D $m R N A$ expression was deternined by Northern blot analysis. In addition, cells were incubated with increasing doses of forskolin (final concentrations: $1,5,10,20$, and $30 \mu \mathrm{mol} / \mathrm{L}$ ) for 6 hours.

RESULTS: When treated with the various mitogens, cells increased their stimulation of PTP1D $m R N A$ expression in a time- and dose-dependent fashion. Specifically, forskolin, EGF, and IGF-I induced maximal $m R N A$ cxpression at 6, 3, and 6 hours, respectively. Expression induced by forskolin, EGF, and IGF-I was five, three, and six times control levels, respcctively. At a dose of $10 \mu \mathrm{mol} / \mathrm{L}$, forskolin induced PTP1D $m R N A$ expression almost two times higher than control values.

Conclusion: These data suggest that in human endometrial carcinomas, $C A M P, E G F$, and IGF-I may regulate the expression of PTP1D $m R N A$, which may, in tum, play a role in uncontrolled cell proliferation and neoplastic transformation. (J Soc Gynecol Invest 1997;4:310-315) Copyright (C) 1997 by the Society for Gynecologic Investigation.
\end{abstract}

KeY words: Peptide growth factors, PTP11), EGF, IGF-I, forskolin, cAMP, HEC-1-A.

靠 rotein tyrosine phosphatases (PTPases) are a family of cytosolic and transmembrane proteins that participate in the delicate balance of tyrosine phosphorylation/ dephosphorylation and thus play a role in the regulation of cell growth, development, and differentiation. Some of these PTPases act to enhance transduction of signals from receptor tyrosine kinases to the nucleus, whereas others act in a negative regulatory role. ${ }^{1.2}$ One such enzyme, protein tyrosine phosphatase 1D (PTP1D; also known as Syp, SHPTP2, SHPTP3, and $\mathrm{PTP} 2 \mathrm{C}$ ), is a ubiquitously expressed cytosolic PTPase that contains two Src homology (SH2) domains at its amino terminus. ${ }^{3.4}$ These domains have been shown to associate with the cytoplasmic domains of the epidermal growth factor (EGF), insulin-like growth factor-I (IGF-I), and platelet-derived growth factor receptors ${ }^{3,4}$ as well as with the intermediate signaling protein, insulin receptor substrate-1 (IRS-1). ${ }^{.}$In addition, the activity of PTP1D has been shown to be ligand

From the Department of Obitetrics and Gynecology. University of Michigan Medical Center. Ann Arbor. Michigan

Address correspondence and reprint requests to: K. M. J. Menon, Phl ), Department of Obstetrits and Gynecology. University of Michigm Medical Center, 6428 Med Soi 1 130: Catherine Street, Am Artor, Mi +810)-(1)(17

Copyright is 1997 by the Socicty for Gynecologic Investigation. Pubiished by Elsevier Science Inc. dependent, requiring phosphorylation of tyrosine residues after autophosphorylation of tyrosine kinase receptors. ${ }^{4}$ Although the role of this PTPase in signal transduction is not understood completely, microinjection of anti-PTP11) antibody and GST-SH2 fusion protein into mouse fibroblasts after stimulation with EGF and IGF-I has demonstrated decreased mitogenesis.' Thus, its role appears to be positive in the signaling cascade after receptor tyrosine kinase activation.

Previous work from our laboratory has shown that peptide growth factors and substances that increase intracellular cyclic adenosine monophosphate (CAMP) levels produce mitogenesis in the endometrial cell line HEC-1-A. ${ }^{7,8}$ Because growth and proliferation of HEC-1-A cells are stimulated by forskolin (an agent that stimulates intracellular cAMP levels), EGF, and IGF-I by tyrosine phosphorylation, the present studies were conducted to examine whether, in endometrial carcinoma, PTP1D mRNA expression is positively linked to the increase in proliferative activity stimulated by EGF, IGF-1, and forskolin (cAMP). Our results show that all three mitogens stimulate the expression of PTP1D mRNA in the endometrial adenocarcinoma cell line $\mathrm{HEC}-1-\mathrm{A}$.

$1071-5576 / 47 / 51700$ PII SI:17) -5576(97) (1) 


\section{MATERIALS AND METHODS}

\section{Cell Line Culture and Treatment}

The HEC-1-A (HTB-112) cell line was purchased from the American Type Culture Collection (Rockville, MD). The cells were cultured in $75-\mathrm{cm}^{3}$ flasks (Becton Dickinson, Lincoln Park, NJ) and maintained in Phenol red-free Dulbecco's modified Eagle's medium/Ham's nutrient mixture F12 (DME/F12; Sigma, St. Louis, MO) supplemented with $10 \%$ fetal bovine serum (FBS), $1.2 \mathrm{~g}$ sodium bicarbonate, $50 \mu \mathrm{g} / \mathrm{mL}$ gentamicin, and $2 \mathrm{U} / \mathrm{mL}$ nystatin. The culture medium was adjusted to $\mathrm{pH} 7.35$ before filtration (Nalgene, Rochester, NY). Cultures were maintained under sterile conditions at $37 \mathrm{C}$ in a humidified environment containing $5 \% \mathrm{CO}_{2}$. For experiments, the cells were detached with fresh trypsin $(0.02 \%) /$ ethylenediaminetetra-acetic acid for 10 minutes. Fresh medium was added and the cell suspension was centrifuged at $150 \times g$ for 10 minutes. The supernatant was discarded and the cell pellet was resuspended in fresh medium. Cells were dispensed into 100 - $\mathrm{mm}$ tissue culture dishes (Becton Dickinson) and were grown to confluence. When the effect of test substances was examined, the cells were preincubated for 24 hours in DME/F12 supplemented with $0.3 \%$ bovine serum albumin (BSA), $50 \mu \mathrm{g}$ gentanicin, and $2 \mathrm{U} / \mathrm{mL}$ nystatin. Stock solutions were made of EGF and forskolin (Sigma) and IGF-1 (a gift from the Eli Lilly Research Laboratories, Indianapolis, IN), and aliquots were added to the cultured cells. All experiments were repeated at least three times, and representative results from a single experiment are presented.

\section{RNA Extraction, Northern Blot, and Hybridization}

Total RNA was extracted using the procedure of Chomczynski and Sacchi." Briefly, $2 \mathrm{~mol} / \mathrm{L}$ sodium acetate, $\mathrm{pH} 4.0$, was added to cell lysates and extracted with water-saturated phenol and chloroform:isoamyl alcohol (49:1). RNA was precipitated with one volume of isopropyl alcohol and was quantified spectrophotometrically. Total RNA was separated by electrophoresis in a $1.2 \%$ agarose gel containing $3 \%$ formaldehyde, blotted to a nitrocellulose membrane (Millipore, Bedford, MA) using $10 \times$ standard saline citrate (SSC), pH 7.0), and ultraviolet-crosslinked with $12 \mathrm{~mJ}$ in a UV-Stratalinker (Stratagene, La Jolla, CA). ${ }^{11}$ Northern blots were prehybridized in a solution containing $1 \times$ Denhardt's, $10 \mathrm{~mL} 20 \times$ saline sodium phosphate ethylenediaminetetra-acetic acid, $20 \mathrm{~mL}$ deionized formanide, and $100 \mu \mathrm{g} / \mathrm{mL}$ salmon sperm DNA. Complementary DNA probes (a Bluescript plasmid containing the PTP1D insert; a generous gift from Dr. Mohammed Adam, Merck-Frosst Centre, Quebec, Canada) were radiolabeled using $\left[\alpha-{ }^{32}\right.$ P $]$ dCTP (ICN, Costa Mesa, CA) and the random primed labeling procedure outlined by Feinberg and Vogelstein. ${ }^{11}$ After hybridization overnight in fresh buffer ( $\mathrm{Hy}$ bridizer 700 ; Stratagene) at $37 \mathrm{C}$, the blots were washed twice with $2 \times$ SSC, $0.1 \%$ sodium dodecyl sulfate (SIS) at room temperature for 20 minutes, once with $0.1 \times$ SSC, $0.1 \%$ SDS

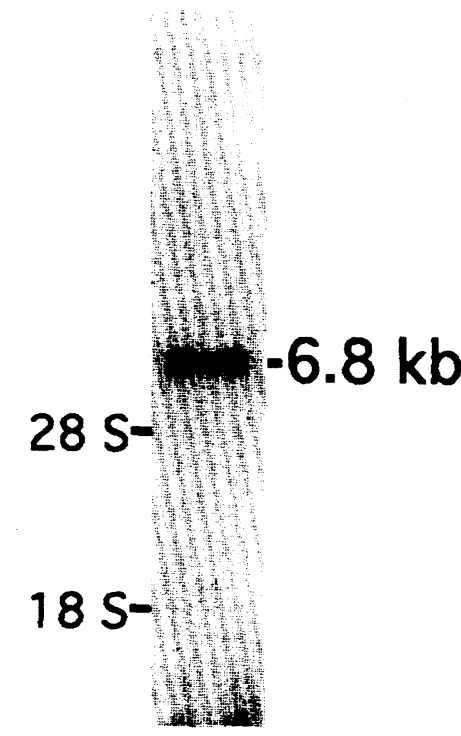

Figure 1. Presence of PTP1D in the human endometrial carcinoma cell line HEC-1-A. HEC-1-A cells were grown to confluence in a $1(0)-\mathrm{mm}$ culture dish and were serum starved for 24 hours. Cells were harvested, total RNA was extracted, and Northem blot hybridization was performed. The PTP1D mRNA was present in relative abundance and corresponds with a previously reported transcript of $6.8 \mathrm{~kb}$.

at room temperature, and once with $0.1 \times \mathrm{SSC}$ at $50 \mathrm{C}$ for 60 minutes. The blots were exposed to Kodak XAR film at $-80 \mathrm{C}$ for 4 days. In a similar fashion. all blots were stripped by rinsing in boiling water for 15 minutes and were hybridized with a $1.0-\mathrm{kb} \beta$-actin cDNA probe. Autoradiograms were scanned (Scanjet IIC; Hewlett Packard, Palo Alto, CA) using an NIH viewer program (Shareware; National Institutes of Health), and bands were quantified in arbitrary densitometric units.

\section{RESULTS}

Initial experiments were conducted to determine the expression of PTP1I in the endometrial carcinoma cell line HEC$1-\mathrm{A}$ under basal conditions. Cells were grown to confluence in a $100-\mathrm{mm}$ dish with $\mathrm{DME} / \mathrm{F} 12$ and $10 \% \mathrm{FBS}$. Cells were serum-starved for 24 hours and total RNA was extracted, separated on an agarose gel, and hybridized with the PTP11) probe as described earlier. The purpose of preincubation in serum-free medium was to exclude the possible stimulatory effect of growth factors associated with the serum to determine whether PTP1D was expressed under basal conditions. Figure 1 demonstrates the presence of a $6.8-\mathrm{kb}$ transcript in this endometrial carcinoma cell line, which corresponds to PTP1D mRNA. ${ }^{3}$

After establishing the expression of PTP1D mRNA, we conducted further experiments to determine whether growth factors are capable of regulating PTP11) mRNA expression in endometrial carcinoma. For time-course studies, HEC-1-A cells were subcultured in five $100-\mathrm{mm}$ tissue culture dishes and grown to confluence. After 24 hours of preincubation, the media were replaced with fresh, serum-free media. Forskolin 


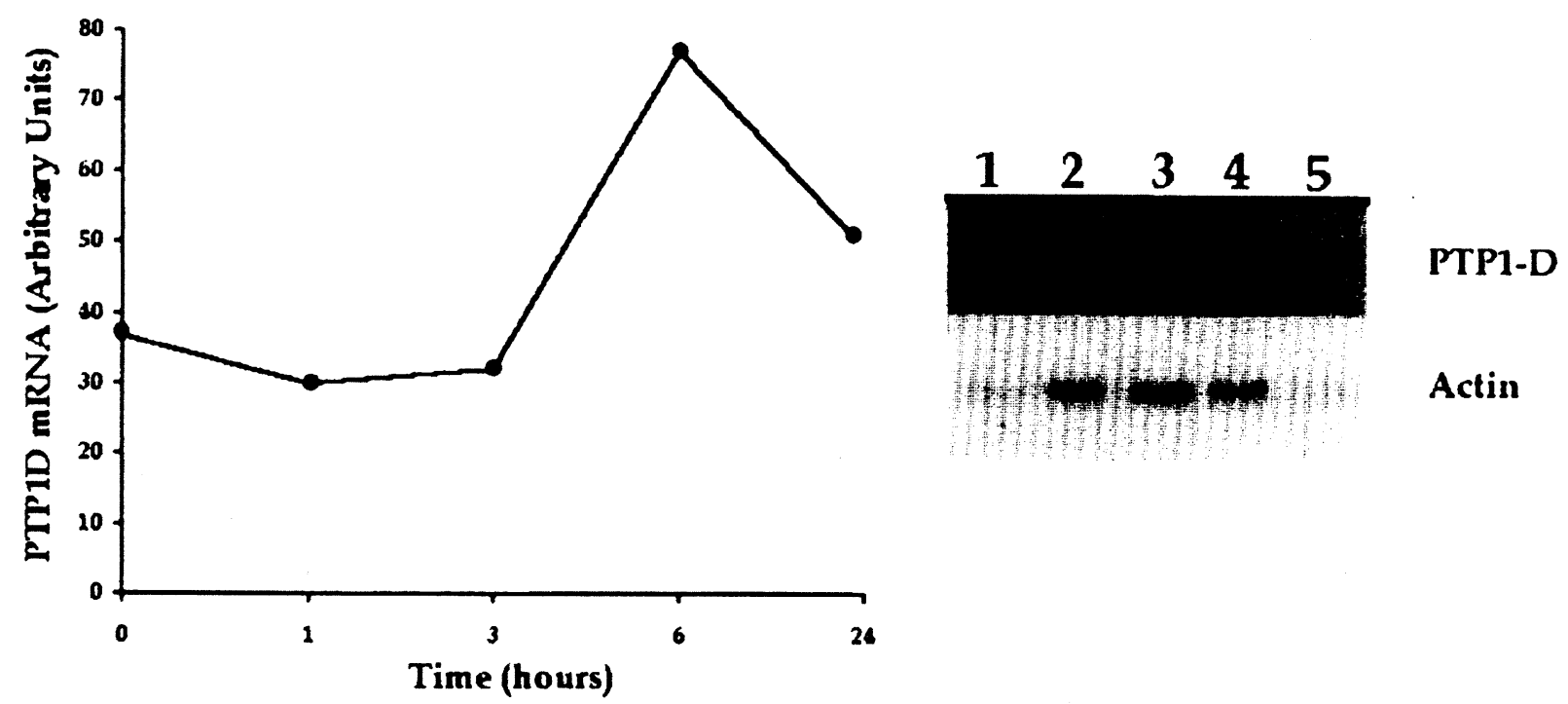

Figure 2. Effects of time of exposure of EGF on PTP1D mRNA expression. HEC-1-A cells were grown to confluence in 100-mm culture dishes and were serum starved for 24 hours. Media were replaced with fresh DME/F12 containing $0.3 \%$ BSA, and EGF was added (final concentration $10 \mathrm{ng} / \mathrm{mL}$ ) and incubated for 24 hours. Cells were harvested at intervals of $0,1,3,6$, and 24 hours, total RNA was extracted, and Northern hybridization was performed by using PTP1D cDNA probe. Hybridization bands were quantified from autoradiograms in densitometric units and were normalized to actin. The ordinate represents the ratio of PTP1D nRNA to actin mRNA. PTP1D = protein tyrosine phosphatase 1D.

was added to four tissue culture dishes to a final concentration of $10 \mu \mathrm{mol} / \mathrm{L}$. Cells were lysed, and total RNA was extracted at $0,1,3,6$, and 24 hours after treatment with forskolin. Similar experiments were performed with EGF $(10 \mathrm{ng} / \mathrm{mL})$.

Figures 2-4 demonstrate that the stimulatory effect of these mitogens on PTP1D mRNA expression was time dependent. Specifically, forskolin induced maximal expression of $\mathrm{mRNA}$ at 6 hours, five times the control level, with return to the baseline by 24 hours. The peak PTP1D mRNA response occurred at 3-6 hours for both EGF and IGF-I.

To characterize further the regulation of PTP1D mRNA expression in this endometrial carcinoma, we subcultured HEC-1-A cells in a series of six 100-mm tissue culture dishes, grew them to confluence, and incubated them with increasing doses $(1,5,10,20$, and $30 \mu \mathrm{mol} / \mathrm{L})$ of forskolin for 6 hours. Total RNA was extracted, and Northern blots were performed
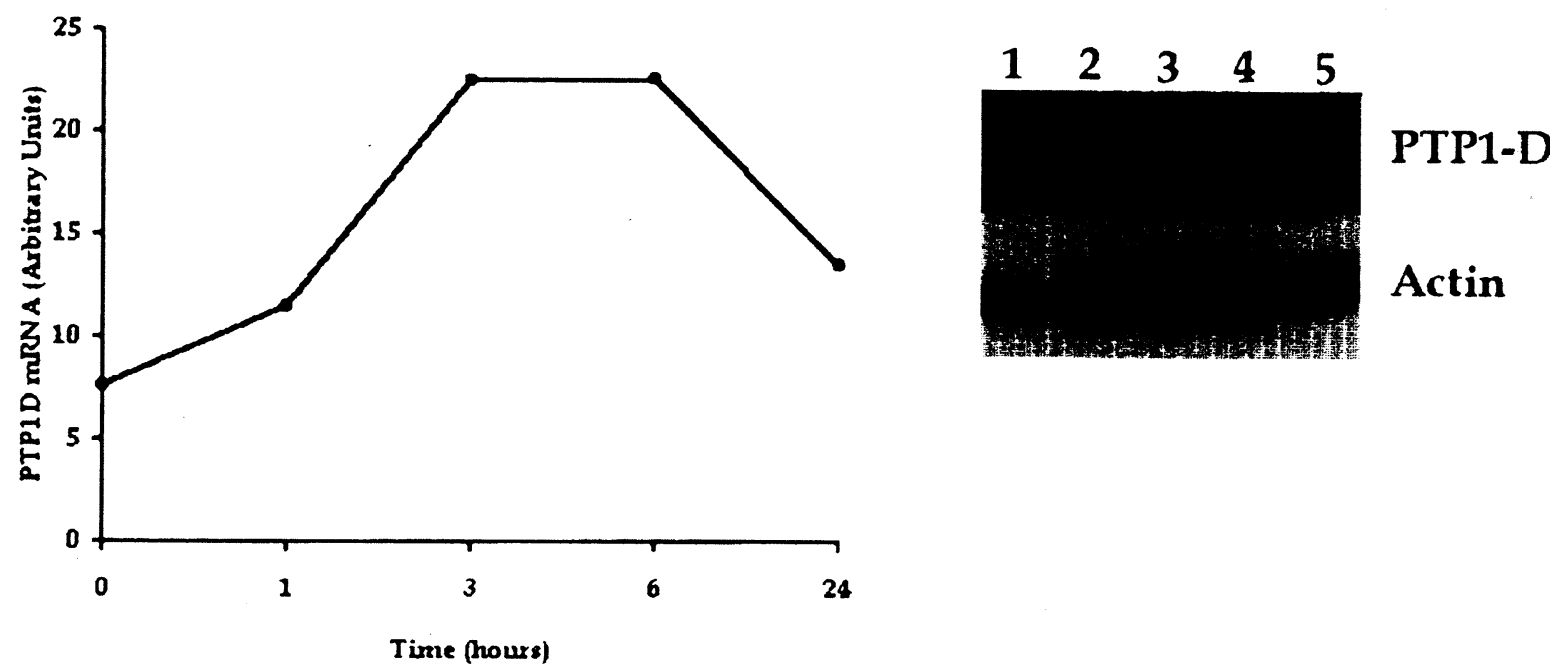

Figure 3. Effects of time of exposure of IGF-I on PTP1D mRNA expression. HEC-1-A cells were grown to confluence in 100-mm culture dishes and were serum starved for 24 hours. Media were replaced with fresh DME/F12 containing $0.3 \%$ BSA, and IGF-I was added (final concentration $100 \mathrm{ng} / \mathrm{mL}$ ) and incubated for 24 hours. Cells were harvested at intervals of $0,1,3,6$, and 24 hours, total RNA was extracted, and Northern hybridization was performed by using PTP1D cDNA probe. Hybridization bands were quantified from autoradiograms in densitometric units and were nommalized to actin. The ordinate represents the ratio of PTP1D mRNA to actin mRNA. Abbreviation as in Figure 2. 

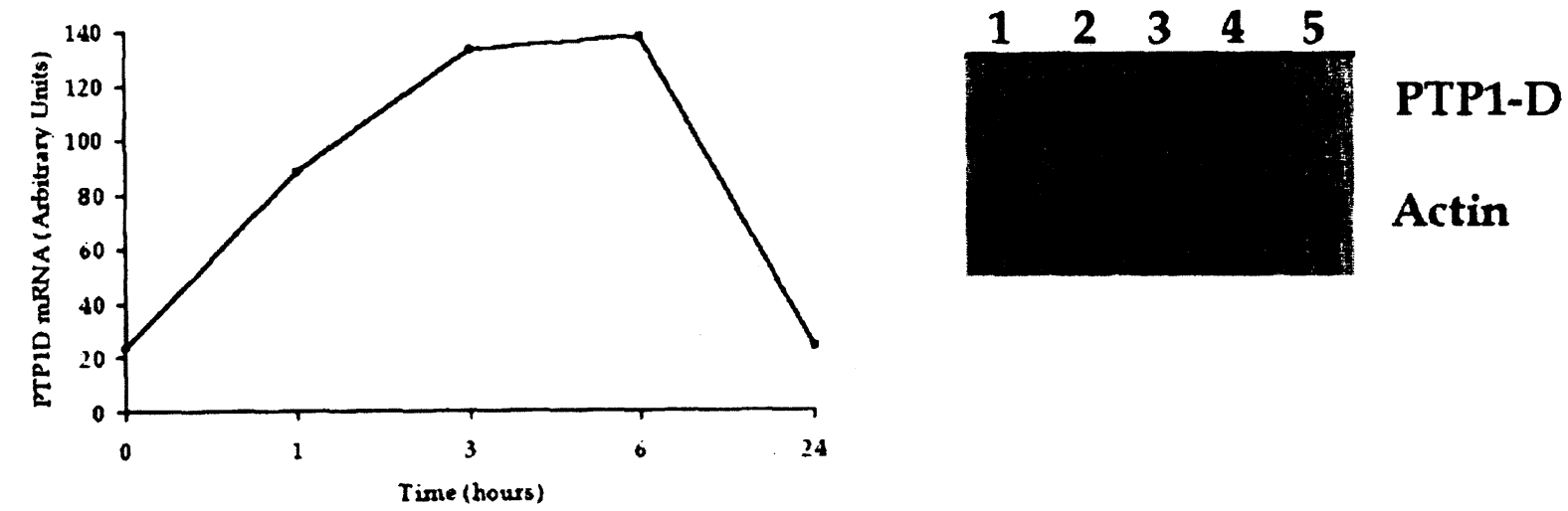

Figure 4. Effects of time of exposure of forskolin on PTP1D mRNA expression. HEC-1-A cells were grown to confluence in 100-mm culture dishes and were serum starved for 24 hours. Media were replaced with fresh DME/F12 containing $0.3 \%$ BSA, and forskolin was added (final concentration $10 \mu \mathrm{mol} / \mathrm{L}$ ) and incubated for 24 hours. Cells were harvested at intervals of $0,1,3,6$, and 24 hours, total RNA was extracted, and Northern hybridization was performed by using PTP1D cDNA probe. Hybridization bands were quantified from autoradiograms in densitometric units and were normalized to actin. The ordinate represents the ratio of PTP1D mRNA to actin mRNA. Abbreviation as in Figure 2.

using a $\left[{ }^{32} \mathrm{P}\right]$-labeled PTP1D cDNA probe. Figure 5 demonstrates that the effect of forskolin on PTP1D mRNA expression was dose dependent. The dose responses of EGF and IGF-I were not tested because our previous studies ${ }^{7,8}$ showed that the selected doses of these growth factors stimulate mitogenesis of HEC-1-A cells.

\section{DISCUSSION}

PTP1D is a nonmembrane, protein tyrosine phosphatase, that contains two SH2 domains. PTP1D, also known as SHPTP2, Syp, PTP2C, and SHPTP3, is a ubiquitously expressed protein that is homologous to the Drosophila gene product corkscre'w (csw). ${ }^{12}$ In mammalian cells, the gene encodes a $6.8-\mathrm{kb}$ message, which in turn translates into a $68-\mathrm{kD}$ a protein,,$^{2-4}$ the full function of which is still being elucidated. However, recent work has shown that PTP1D is a positive mediator of growth factor-stimulated mitogenesis," serving as an adapter between receptor tyrosine kinases and the Grb-SOS complex. ${ }^{12,13}$ In previous studies from our laboratory, we established that EGF, the IGFs, insulin, and forskolin stimulate mitogenic activity of the human endometrial cancer cells HEC-1-A and KLE. ${ }^{7,8}$ In our effort to understand how the growth of endometrial carcinoma may be regulated by these growth factors, we examined the expression and inducibility of PTP1D in response to EGF, IGF-I, and forskolin in HEC-1-A cells.

Our studies show that the endometrial carcinoma cell line HEC-1-A expresses PTP1D mRNA with a transcript size comparable to that reported in other cell types. ${ }^{2-4}$ The expression of PTP1D mRNA transcript was induced by EGF, IGF-I, and forskolin in a time-dependent manner. The induction of the mRNA transcript in response to EGF, IGF-I, and forskolin occurred at concentrations that have been shown to
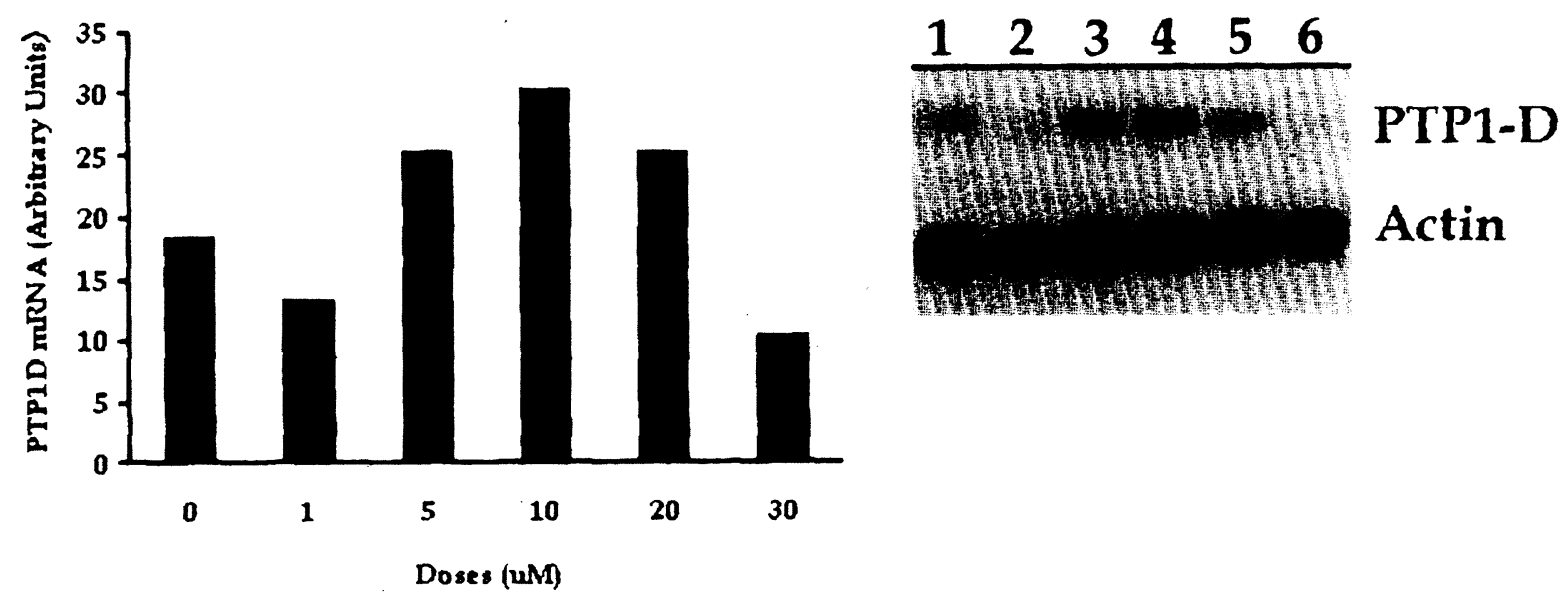

Figure 5. Effects of dose of forskolin on PTP1D mRNA expression. HEC-1-A cells were grown to confluence in 100-mm culture dishes and were serum starved for 24 hours. Media were replaced with fresh DME/F 12 containing $0.3 \%$ BSA, and forskolin was added to a final concentration of $1,5,10,20$, or $30 \mu \mathrm{mol} / \mathrm{L}$ and incubated for 6 hours. Cells were harvested, total RNA was extracted, and Northern hybridization was performed by using PTP1D cDNA probe. Hybridization bands were quantified from autoradiograms in densitometric units and were normalized to actin. The ordinate represents the ratio of PTP1D mRNA to actin mRNA. Abbreviation as in Figure 2 . 
stimulate mitogenesis. ${ }^{7.8}$ Although we have not determined whether the effect of these stimulatory agents on PTP1D mRNA is due to increased gene expression or decreased degradation of the transcript, the present studies implicate PTP1I as a probable intermediate in growth factor-mediated mitogenesis.

During hyperplasia and carcinogenesis, the proliferative and differentiating activity of the endometrium becomes deregulated and endometrial cells progress to stages of rapid growth, immortalization, invasiveness, metastasis, and angiogenesis. Insulin-like growth factor-I, a tyrosine kinase receptor, has been shown to be a key factor involved in the phenotypic transformation of various cell types. Sell et al ${ }^{14}$ showed that simian virus 40 large antigen was unable to transform mouse embryonic fibroblasts that lacked the IGF-I receptor. Similarly, the ability of the IGF-I receptor to facilitate the transforming capacity of the EGF receptor was demonstrated in wild-type mouse embryo cells. Coppola et $\mathrm{al}^{15}$ showed that when the EGF receptor expression plasmid was overexpressed in cells derived from littermate embryos that had the IGF-I receptor genes disrupted, those cells were resistant to transformation despite reintroduction of the wild-type IGF-I receptor. Other studies from our laboratory have further demonstrated that the IGF-I receptor is highly expressed in neoplastic endometrium. ${ }^{16}$

The current studies also support the hypothesis that signaling pathways are not isolated from each other, but converge to produce "crosstalk" and activate a series of events that result in cell proliferation and possibly malignancy. Our laboratory has shown that the mitogenic response of the endometrial adenocarcinoma cell line HEC-1-A to IGF-I is enhanced when the cells are preincubated with agents that increase intracellular cAMP. ${ }^{\circ}$ Other studies ${ }^{17-19}$ have shown that prostaglandins increase cAMP accumulation in endometrial cells. Thus, the effects of EGF and IGF-I in endometrial cell proliferation, and possibly in malignant transformation, could be enhanced by prostaglandins in vivo.

Insulin-like growth factor receptor substrate 1 has been identified in different cell types ${ }^{20-22}$ as the mediator of IGF-1 action. One likely mechanism by which IRS-1 phosphorylation is enhanced may involve the action of protein tyrosine phosphatases (PTPases). Studies by Kuhne et al ${ }^{5}$ and Milarski and Saltiel, ${ }^{1.3}$ have shown that upon activation of insulin receptor, IRS-I undergoes phosphorylation at multiple tyrosine residues and forms a complex with PTP1D. The IRS-I/ PTP1D complex further associates with Grb-SOS, leading to the activation of ras-mediated mitogen-activated extracellular signal regulated protein kinase kinase (mitogen-activated protein kinase kinase) phosphorylation, culminating in mitogenesis. Similarly, Xiao et $\mathrm{al}^{\mathrm{h}}$ and Rivard et al ${ }^{2.3}$ have shown that when PTP11) is blocked by either an anti-Syp antibody or an inactive GST-SH2 protein, fibroblasts that have been serum starved and then stimulated with EGF fail to proliferate.

The site of action of PTP1D in mitogenic signaling is not completely understood. Studies by Milarski and Saltiel ${ }^{1.3}$ showed that expression of a catalytically inactive mutant of PTP1D completely blocked stimulation of the MAP kinase pathway by insulin as well as insulin-induced mitogenesis. Tyrosine phosphorylation of the insulin receptor, or tyrosine phosphorylation of IRS-1 or Shc, was not affected by the expression of the dominant negative PTP1I). ${ }^{13}$ Evidence also suggests that catalytically inactive PTP1D does not interfere with the binding of Grb2 to IRS-1 or formation of the Shc-Grb2 complex. ${ }^{24}$ These studies suggest that PTP1D acts downstream of initial phosphorylation leading to ras activation, upstream of MAP kinase. Further studies by Sawada et al ${ }^{25}$ have shown that catalytically inert PTP1D blocked activation of both MEK and raf-1 kinase by insulin, suggesting that PTP1D might exert its growth-promoting effect by acting at a step downstream of $\mathrm{p} 21^{\text {ras }}$. On the basis of our studies, we conclude that the mitogenic stimulation of HEC-1-A cells by EGF, IGF-I, and forskolin may be mediated by induction of PTP(1). PTP11), in turn, may exert its effect on mitogenesis by acting at a step either upstream or downstream of $\mathrm{p} 21^{\text {ras }}$.

Our studies suggest that PTP1D may play a crucial role in the mitogenic stimulation of HEC-1-A cells by EGF, IGF-I, and forskolin. The finding that PTP1D mRNA may be induced by forskolin is a novel observation not described previously. Although the involvement of PTP1D in the mitogenic signaling pathways of EGF and IGF-1 in this endometrial carcinoma cell line needs to be substantiated with further experimental work, its inducibility by these peptide growth factors and substances that increase intracellular cAMP levels further supports its involvement in mitogenesis. Further evaluation of PTP1D is necessary to elucidate its precise function in the malignant transformation of endometrial cells.

\section{REFERENCES}

1. Mauro LJ, Dixon JE. 'Zip codes' direct intracellular protein tyrosine phosphatases to correct cellular 'addresses.' Trends Biochem Sci 1994;19:35-45.

2. Sun H, Tonks NK. The coordinated action of protein tyrosine phosphatases and kinases in cell signaling. Trends Biochem Sci 1994;19:480-5.

3. Vogel W, Lammers R, Huang J, Ullich A. Activation of phosphotyrosine phosphatase by tyrosine phosphorylation. Science 1993;259:1611-3.

4. Feng GS, Hui CC, Pawson T. SH2-containing phosphotyrosine phosphatase as a target of protein tyrosine kinases. Science 1993; 259:1607-11

5. Kuhne MR, Pawson T, Leinhard (iE, Feng GS. The insulin receptor substrate 1 associates with the SH2-containing phosphotyrosine phosphatase Syp. J Biol Chem 1993;263:11479-81.

6. Xiao S, Rose DW. Sasaoka T, et al. Syp (SH-PTP2) is a positive mediator of growth factor-stimulated nuitogenic signal transduction. J Biol Chem 1994;269:21244-8.

7. Pearl ML, Talavera F, Gretz HF III, Roberts JA, Menon KMJ. Mitogenic activity of growth factors in the human endometrial adenocarcinoma cell lines HEC $-1-A$ and KLE. Gynecol Oncol 1933;49:325-32.

8. Talavera F, Bergman C, Pearl ML, Conner P, Roberts JA, Menon KMJ. CAMP and PMA enhance the effects of IGF-1 in the proliferation of endometrial adenocarcinoma cell line HEC$1-A$ by acting at the $G_{1}$ : phase of the cell cycle. Cell Prolif 1995;28:121-36

9. Chomczynski P, Sacchi N. Single-step method of RNA isolation 
by acid guanidinium thiocyanate-phenol-chloroform extraction. Anal Biochem 1987;162:156-9.

10. Sambrook J, Fritsch EG, Maniatis T. Molecular cloning: A laboratory manual. 2nd ed. Cold Spring Harbor, New York: Cold Spring Harbor Laboratory Press, 1989:1.21-1.j2.

11. Feinberg AP, Vogelstein B. Random oligonucleotide primed labeling: An alternative to nick translation. Anal Biochen 1983; 132:6-13.

12. Perkins LA, Larsen I, Perrimon N. Corkscrew encodes a putative protein tyrosine phosphatase that functions to transduce the terminal signal from the receptor tyrosine kinase torso. Cell 1992; 70):225-39.

13. Milarski KL, Saltiel AR. Expression of catalytically inactive Syp phosphatase in $3 T 3$ cells blocks stimulation of mitogen-activated protein kinase by insulin. J Biol Chem 1994;269:21239-43.

14. Sell C, Rubini M, Rubin R, Liu JP, Efstratiadis A, Baserga R. Simian virus 40 large tumor antigen is unable to transform mouse embryonic fibroblasts lacking type 1 insulin-like growth factor receptor. Proc Natl Acad Sci USA 1993;90:11217-21.

15. Coppola D, Ferber A, Miura M, et al. A functional insulin-like growth factor-I receptor is required for the mitogenic and transforming activities of the epidermal growth factor receptor. Mol Cell Biol 1994;14:4588-95.

16. Talavera F, Reynolds RK, Roberts JA, Menon KMJ. Insulin-like growth factor-I receptors in nomal and neoplastic human endometrium. Cancer Res 1990;50:3019-24.

17. Orlicky DJ, Lieberman R, Williams C, Gerschenson LE. Binding and messengers of prostaglandin $F 2 \alpha$ and $E 1$ in primary cultures of rabbit endometrial cells. J Cell Physiol 1986;127:61-72.
18. Yee GM, Kennedy TG. Role of cyclic adenosine $3^{\prime}, 5^{\prime}$ monophosphate in mediating the effect of prostaglandin $\mathrm{E}_{2}$ on decidualization in vitro. Biol Reprod 1991;45:163-71.

19. Yee GM, Kennedy TG. Prostaglandin $E_{2}$, cAMP dependent protein kinase isozymes during decidualization of rat endometrial stromal cells in vitro. Prostaglandins 1993;46:117-38.

20. White MF, Maron R, Kahn C.R. Insulin rapidly stimulates tyrosine phosphorylation of a $\mathrm{Mr} 185,000)$ protein in intact cells. Nature 1985:318:183-6.

21. Giorgetti S, Balloti R, Kowalski-Chauvel A, Sophie T, Obberghen EV. The insulin and insulin-like growth factor-I receptor substrate IRS-I associates with and activates phosphatidylinositol 3-kinase in vitro. J Biol Chem 1993;268:7358-64.

22. Backer JM, Myers MG Jr, Shoelson SE, et al. Phosphatidylinositol 3-kinase is activated by association with IRS-I during insulin stimulation. EMBO J 1992:11:3469-79.

23. Rivard N, McKenzie FR, Brondello JM, Pouyssegur J. The phosphotyrosine phosphatase PTP1D, but not PTP1C, is an essential mediator of fibroblast proliferation induced by tyrosine kinase and G protein coupled receptors. J Biol Chem 1995;27(): 11017-24.

24. Noguchi T, Matozaki T, Horita K, Fujioka Y, Kasuga M. Role of SH-PTP2, a protein-tyrosine phosphatase with Sre homology 2 domains, in insulin stimulated Ras activation. Mol Cell Biol 1994;14:6674-82.

25. Sawada T, Milarski KL, Saltiel AR. Expression of a catalytically inert Syp blocks activation of MAP kinase pathway downstream of $221^{\text {ras }}$. Biochem Biophys Res Commun 1995;214:737-43. 